\title{
Environmental Education for Prevent Disaster: A Survey of Students Knowledge in Beginning New Normal of COVID-19
}

\author{
Feryl Ilyasa', Henita Rahmayanti ${ }^{1 *}$, Muzani1' Ilmi Zajuli Ichsan1, Suhono ${ }^{2}$ \\ 1 Universitas Negeri Jakarta, Indonesia \\ 2 Institut Agama Islam Ma'arif NU Metro Lampung, Indonesia
}

Corresponding Author: Henita Rahmayanti, henita.rahmayanti@unj.ac.id

\section{ABSTRACT}

\begin{abstract}
The purpose of this study was to determine the importance of implementing disaster mitigation education in schools during the new normal era of Coronavirus Disease 2019 (COVID-19). The method in this research used descriptive research design using a survey study approach. The research instrument used was a knowledge test with the number of questions as many as 15 items. The sample used was senior high school students who were randomly selected. The level of good and lack of

knowledge is determined based on the average total score. A good level of knowledge has a condition> 111.76, while a level of knowledge that lacks a condition $<111.76$. The results of this study are that the majority of respondents have a total score that is less with a mean score of 101.94, while respondents who have a good number of scores have an average score of 127 . Overall respondents have an average of 111.76. Then conducted an Independent Sample t-test with the result that there are differences in the number of good disaster mitigation knowledge scores on respondents with the number of disaster mitigation knowledge scores that are less on respondents with a p-value of 0,000 with a degree of freedom is $95 \%$. The implementation of disaster education in the new normal era is important to continue to prevent transmission of COVID19. The conclusion of this study is the score of students' knowledge about disaster needs to be improved in the new normal era.
\end{abstract}

ARTICLE INFO

Article history:

Received

June 27, 2020

Revised

July 14, 2020

Accepted

July 18, 2020

How to cite

Journal Homepage Published by
Keywords: Disaster Mitigation Education, Disaster Mitigation Knowledge, New Normal COVID-19

Ilyasa. F., Rahmayanti, H., Muzani, M., Ichsan, I. Z., \& Suhono, S. (2020). Environmental Education for Prevent Disaster: A Survey of Students Knowledge in Beginning New Normal of COVID-19. IJoASER (International Journal on Advanced Science, Education, and Religion), 3(2). 1-8 https://doi.org/10.33648/ijoaser.v3i2.60 https:/ / ojs.staialfurqan.ac.id/IJoASER/ STAI Al-Furqan Makassar

\section{INTRODUCTION}

A disaster is a natural phenomenon or an event phenomenon that can have a wide-ranging impact on society (Dahl \& Millora, 2016; Onuma et al., 2017; Storr et al., 2017). The impact caused by the occurrence of the disaster to the wider community, it is necessary to have qualified knowledge through disaster mitigation education in environmental learning (Crow \& Albright, 2019; Rahmayanti et al., 2020; Storr et al., 2017). The provision of disaster mitigation education is very important and must be carried out continuously and routinely including when the pandemic of Coronavirus Diseases 2019 (COVID-19) occurs. 
Disaster mitigation is an activity carried out before a disaster occurs and which focuses on reducing impacts, as well as preparedness and efforts to reduce the impact of long-term disasters (Burrascano et al., 2016; Kauffman et al., 2016). Then another understanding of disaster mitigation is a mitigation activity that aims to be able to increase community preparedness and to reduce risk from disasters for the long term, reduce the number of victims, and apply as much as possible to reduce the impact of disasters (Muzani et al., 2020). The application of mitigation education is very important, so it needs to be applied at all levels of the school (Rahmayanti et al., 2020). This application is to provide a deepening of knowledge and readiness for actions that need to be taken before an unexpected natural disaster occurs to be able to reduce all impacts and also the risk of disaster (Crow \& Albright, 2019; Pickett et al., 2019). Mitigation education gives rise to the ability to think and act effectively when disasters occur. Disaster mitigation education is also expected to develop the character of empathy and willingness to be able to help others carefully (Siriwardena et al., 2013). Disaster mitigation education must continue to be carried out when the Coronavirus Disease 2019 (COVID-19) pandemic occurs. That is because COVID-19 is also a type of disaster. It became an important matter when entering the new normal era of COVID19.

Disaster mitigation education needs to be introduced at the school level in Indonesia (Rahmayanti et al., 2020). This is a preparation from the people of Indonesia in dealing with natural disasters. this disaster mitigation education must be included in the education curriculum, especially on subjects that have correlations or relationships within it (Muzani et al., 2020). The application of lessons learned from disaster mitigation education can reduce risks resulting from the occurrence of natural disasters (Storr et al., 2017). Based on this description, the purpose of this study was to describe students' knowledge about disaster mitigation during the new normal era.

\section{METHODS}

This research had employed a qualitative research with case study type. Because this study seeks to describe and analyze phenomena, events, social activities, attitudes, and perceptions of a person or group (Killam \& Heerschap, 2013; Conway, 2014). This research was conducted during June 2020, this month was the beginning of the entry of the New Normal period of COVID-19 in Indonesia. The use of this descriptive research design in the research aims to find out the importance of applying disaster mitigation education in schools. Data collection is a procedure carried out systematically and standardized to be able to obtain data. In this regard, based on the type of research and the types of data sources used and those that have been determined, the data collection technique in this study is to use a questionnaire that will be distributed to 51 respondents who are students. The type of questionnaire that will be given to respondents is in the form of a test item, which has 15 item questions. The data used in this study are primary, i.e. data obtained directly by researchers and secondary data, i.e. data obtained from relevant research results and other information.

\section{RESULT AND DISCUSSION}

The results of this study indicate that student scores are still dominated in the less category. While other details about respondents' scores can be seen in table 1 . In addition to the scores obtained by respondents, table 1 also describes gender, age, and interval scores. 
Table 1. Frequency Distribution of Respondents

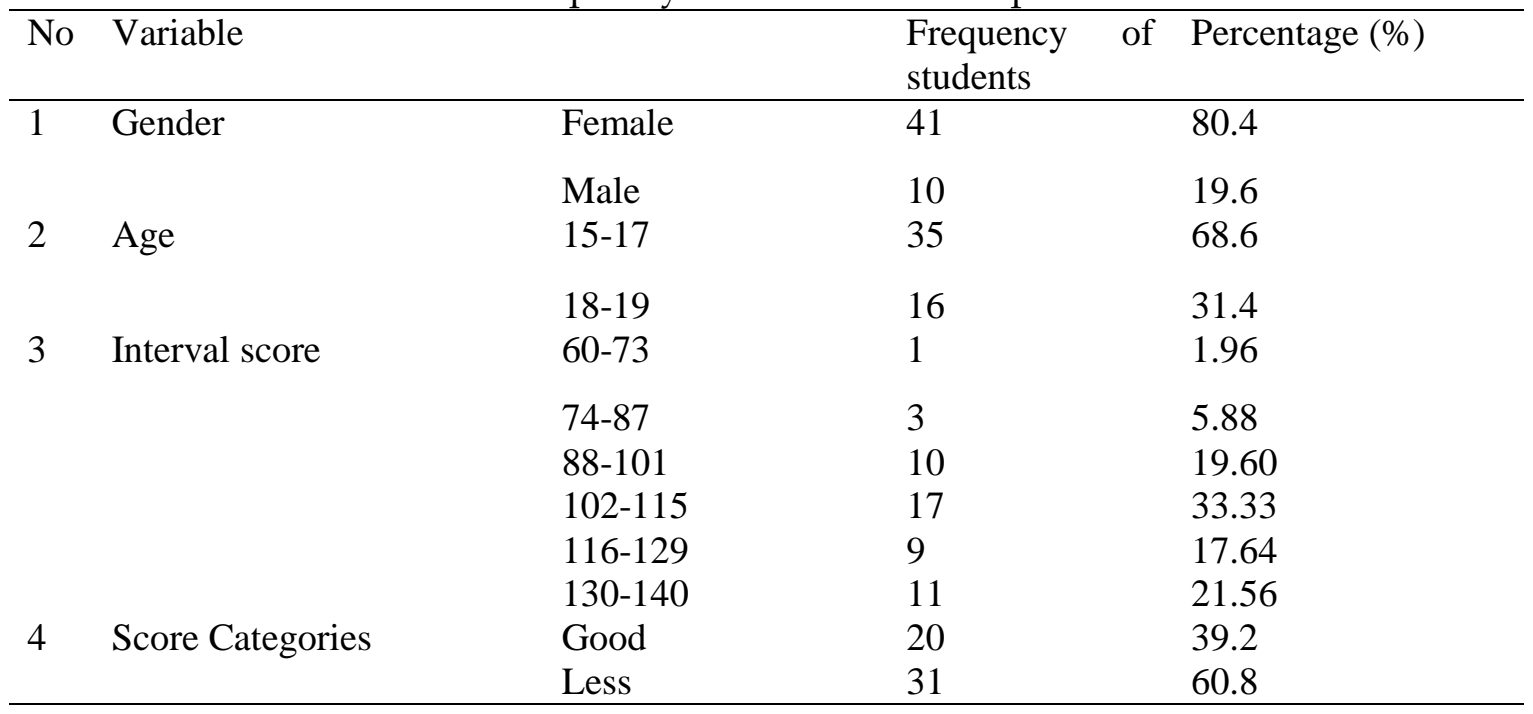

Based on the results contained in Table 1 regarding the frequency distribution of respondents, it can be seen that there are four main variables, namely the gender variable, the age or age variable, the total score variable, and the knowledge level variable. The table above explains the variables measured using the research instrument, the questionnaire. From the four variables measured by the researcher, it can be explained that the majority of respondents are women, with a percentage of $80.4 \%$. Then in the second variable, the majority are students aged $15-17$ years, with a percentage of $68.6 \%$. Then there is the total score variable, the majority of which have a total score between $102-115$ with a percentage of $33.33 \%$. And the last variable is the variable level of knowledge in high school students where the majority of them have a level of knowledge that is still lacking, which is equal to $60.8 \%$.

Table 2. Distribution of Student Responses for each Item

\begin{tabular}{lllll}
\hline Item No & $\begin{array}{l}\text { Frequency of } \\
\text { students } \\
\text { answering } \\
\text { incorrectly }\end{array}$ & $\begin{array}{l}\text { Frequency of } \\
\text { students } \\
\text { answering } \\
\text { correctly }\end{array}$ & $\begin{array}{l}\text { Percentage of } \\
\text { students } \\
\text { answering } \\
\text { incorrectly }\end{array}$ & $\begin{array}{l}\text { Percentage of } \\
\text { students } \\
\text { answering } \\
\text { correctly }\end{array}$ \\
\hline Item 1 & 7 & 44 & 13.70 & 86.30 \\
Item 2 & 1 & 50 & 2.00 & 98.00 \\
Item 3 & 2 & 49 & 3.90 & 96.10 \\
Item 4 & 37 & 14 & 72.50 & 27.50 \\
Item 5 & 2 & 49 & 3.90 & 96.10 \\
Item 6 & 12 & 39 & 23.50 & 76.50 \\
Item 7 & 11 & 40 & 21.60 & 78.40 \\
Item 8 & 1 & 50 & 2.00 & 98.00 \\
Item 9 & 10 & 41 & 19.60 & 80.40 \\
Item 10 & 26 & 25 & 51.00 & 49.00 \\
Item 11 & 3 & 48 & 5.90 & 94.10 \\
Item 12 & 14 & 37 & 27.50 & 72.50 \\
Item 13 & 32 & 19 & 62.70 & 37.30 \\
Item 14 & 29 & 22 & 56.90 & 43.10 \\
Item 15 & 8 & 43 & 15.70 & 84.30 \\
\hline
\end{tabular}


Based on the results contained in Table 2 about the distribution of answers filling questions, it can be seen that the researcher uses the type of questionnaire, namely in the form of a test with the number of questions as many as 15 items. Which of the 15 question items, 37 respondents answered incorrectly on the 4th item question. A total of 50 respondents managed to answer correctly on the questions item 2 and item 8 . Interpretation on the percentage scale can be seen that $72.5 \%$ of respondents answered incorrectly on the 4 th item and as many as $98 \%$ of respondents managed to answer correctly on the 2nd item and the 8 th item.

Table 3. Independent Sample T-Test

\begin{tabular}{llllll}
\hline Score Categories & Frequency & Average & Mean & P-Value & CI \\
\hline Good & 20 & 127 & 111.76 & 0.000 & $95 \%$ \\
Less & 31 & 101.94 & & & \\
\hline
\end{tabular}

Based on the results found in Table 3 about the Independent Sample T-Test, it can be seen that the frequency of respondents who have a good score is 20 respondents with an average number of good scores of 127 . While the number of scores that is less is 31 respondents with an average number of scores that are less is 101.94. From the overall data obtained, the overall average score is 111.76. Determination of categorization of the level of knowledge is based on the average value of the overall score obtained, which is where the level of good knowledge follows the provisions of $>$ 111. 76. Whereas the level of knowledge that does not follow the provisions of $<111.76$. Then, Independent Sample T-Test, which obtained the results at the p-value of 0,000 with a magnitude of $95 \%$ CI. Because the calculation result on the p-value is 0,000 , it can be seen that there are differences in the number of respondents 'good knowledge scores with the respondents' total knowledge scores that are lacking.

The results of this study indicate that student scores still need to be improved about disaster mitigation knowledge. These high-quality resources are only obtained through education. The improvement of high-quality human resources is the highest priority (Boholano, 2017; Camacho \& Legare, 2015; Dwyer et al., 2014). The aim is to realize Indonesian people and people who have character and personality and can master various scientific branches of knowledge, technology, and art, to strengthen the power of competitiveness in the 21st century (Farisi, 2016; Motallebzadeh et al., 2018; Quieng et al., 2015; Seema et al., 2019; Urbani et al., 2017).

Education becomes one of the effective and efficient means to improve the quality of human resources and also to reduce the risk of natural disasters (Muzani et al., 2020).

The method that can be used is to include a variety of subject matter about natural disasters for each student at all levels, especially in schools in areas that are vulnerable to the risk of natural disasters. This natural disaster mitigation education can also be included in the curriculum based on local wisdom, which can be expected to be accepted and can be easily understood by students or students because of the more contextual learning topics (Bustami et al., 2018; Cronje et al., 2011; Kartikaningtyas et al., 2018; Lemus et al., 2014; Paristiowati et al., 2019). Prevention and treatment must be carried out as a disaster mitigation measure, especially regarding hazards and safety measures to be able to consider prevention, mitigation, vulnerability, and resilience development.

Such knowledge can be obtained through experience, both direct experience, and indirect experience. Disaster-related knowledge possessed by high school students 
based on the results of this study is still classified as lacking. This is caused because high school students who were respondents in this study lacked sufficient information related to the disaster. Information about disaster mitigation is important for students. The speed of information is an important factor for students in gaining knowledge about the disaster from the internet (Reyna et al., 2018; Tsai et al., 2015; Velasquez \& Evans, 2018; Yusop \& Sumari, 2013). Therefore it is very important to implement various disaster mitigation education efforts for school students or children. Because by carrying out this disaster mitigation education effort, it can provide them with the knowledge to reduce the risk of a disaster occurring, so that when natural disasters occur that cannot be predicted, we can reduce the number of fatalities, especially many from the age group of children.

Indonesia is currently starting to start the beginning of a new normal. This needs to be continually supported and strengthened with various disaster mitigation education that has been carried out during the physical distancing period at the beginning of 2020. Education about disaster becomes an important thing to do, including COVID-19, which is a disaster that must be resolved together (Abel \& Mcqueen, 2020; Bandyopadhyay, 2020; Basilaia \& Kvavadze, 2020; Toquero, 2020). The new normal era is one of the right times for mitigation education to become more intensive. That is because some economic activities have begun to reopen during the new normal era. The opening of various social and economic activities must also be balanced regarding disaster mitigation education so that the COVID-19 issue can be resolved immediately.

\section{CONCLUSIONS}

Based on the results of this study indicate that the knowledge of high school students is still included in the category of less because the majority of 31 students have less knowledge. According to the Independent Sample T-Test conducted, there is a difference between the number of disaster mitigation knowledge scores that are good for students and the number of disaster mitigation knowledge scores that are lacking in students. The implementation of disaster mitigation education must continue to be improved during the new normal period of COVID-19.

\section{ACKNOWLEDGEMENTS}

Thank you for participant in this research and teacher for help in this research.

\section{AUTHOR CONTRIBUTION STATEMENTS}

First author had contribution for collecting data in this research. Corresponding author was a corresponding person with editor, from submission until publish for this article. Another authors help to improve this research paper before submit to journal.

\section{REFERENCES}

Abel, T., \& Mcqueen, D. (2020). The COVID-19 pandemic calls for spatial distancing and social closeness : not for social distancing ! International Journal of Public Health, 7. https:// doi.org/10.1007/s00038-020-01366-7

Bandyopadhyay, S. (2020). Coronavirus Disease 2019 (COVID-19): we shall overcome. Clean Technologies and Environmental Policy. https://doi.org/10.1007/s10098-02001843-w

Basilaia, G., \& Kvavadze, D. (2020). Transition to online education in schools during a SARS-CoV-2 coronavirus (COVID-19) pandemic in Georgia. Pedagogical Research, 
5(4), 1-9. https://doi.org/10.29333/pr/7937

Boholano, H. B. (2017). Smart Social Networking: 21st Century Teaching And Learning Skills. Research in Pedagogy, 7(1), 21-29. https://doi.org/10.17810/2015.45

Burrascano, S., Chytrý, M., Kuemmerle, T., Giarrizzo, E., Luyssaert, S., Sabatini, F. M., \& Blasi, C. (2016). Current European policies are unlikely to jointly foster carbon sequestration and protect biodiversity. Biological Conservation, 201(May), 370-376. https:// doi.org/10.1016/j.biocon.2016.08.005

Bustami, Y., Syafruddin, D., \& Afriani, R. (2018). The implementation of contextual learning to enhance biology students' critical thinking skills. Jurnal Pendidikan IPA Indonesia, 7(4), 451-457. https://doi.org/10.15294/jpii.v7i4.11721

Camacho, D. J., \& Legare, J. M. (2015). Opportunities to Create Active Learning Techniques in the Classroom. Journal of Instructional Research, 4, 38-45.

Conway, C. M. (2014). The Oxford Handbook of Qualitative Research in American Music Education. Oxford University Press. Google Scholar

Cronje, R., Rohlinger, S., Crall, A., \& Newman, G. (2011). Does Participation in Citizen Science Improve Scientific Literacy? A Study to Compare Assessment Methods. Applied Environmental Education and Communication, 10(3), 135-145. https:// doi.org/10.1080/1533015X.2011.603611

Crow, D. A., \& Albright, E. A. (2019). Intergovernmental relationships after disaster: state and local government learning during flood recovery in Colorado. Journal of Environmental Policy and Planning, 21(3), 257-274. https:// doi.org/10.1080/1523908X.2019.1623660

Dahl, K. K. B., \& Millora, C. M. (2016). Lifelong learning from natural disasters: transformative group-based learning at Philippine universities. International Journal of Lifelong Education, 35(6), 648-663. https:// doi.org/10.1080/02601370.2016.1209587

Dwyer, C. P., Hogan, M. J., \& Stewart, I. (2014). An integrated critical thinking framework for the 21st century. Thinking Skills and Creativity, 12, 43-52. https:// doi.org/10.1016/j.tsc.2013.12.004

Farisi, M. I. (2016). Developing the 21 st-century social studies skills through technology integration. Turkish Online Journal of Distance Education-TOJDE, 17(1), 16-30. https:// doi.org/10.17718/tojde.47374

Kartikaningtyas, V., Kusmayadi, T. A., \& Riyadi, R. (2018). The effect of brain based learning with contextual approach viewed from adversity quotient. Journal of Physics: Conference Series, 1022. https://doi.org/10.1088/17426596/1022/1/012014

Kauffman, J. B., Trejo, H. H., Garcia, M. del C. J., Heider, C., \& Contreras, W. M. (2016). Carbon stocks of mangroves and losses arising from their conversion to cattle pastures in the Pantanos de Centla, Mexico. Wetlands Ecology and Management, 24(2), 203-216. https:// doi.org/10.1007/s11273-015-9453-z

Killam, L. A., \& Heerschap, C. (2013). Challenges to student learning in the clinical setting: A qualitative descriptive study. Nurse Education Today, 33(6), 684-691. https:// doi.org/10.1016/j.nedt.2012.10.008.

Lemus, J. D., Seraphin, K. D., Coopersmith, A., \& Correa, C. K. V. (2014). Infusing traditional knowledge and ways of knowing into science communication courses at the university of hawai'i. Journal of Geoscience Education, 62(1), 5-10. https:// doi.org/10.5408/12-416.1

Motallebzadeh, K., Ahmadi, F., \& Hosseinnia, M. (2018). Relationship between 21st century skills, speaking and writing skills: A structural equation modelling 
approach. International Journal of Instruction, 11(3), 265-276. https:// doi.org/10.12973/iji.2018.11319a

Muzani, Setiawan, C., Putri, F., N. 2020. Middle school preparedness in dealing with, fire disasters in Kampung Melayu village. International Journal of Innovation, Creativity and Change, 258-274, Vol. 12 No.10 https://www.ijicc.net/images/vol12/iss10/121031_Muzani_2020_E_R.pdf

Muzani, Desy Safitri, Arita Marini, Apri Wahyudi. Disaster Mitigation through Disaster Education in Indonesia. JCR. 2020; 7(12): 13441350. http:// www.jcreview.com/?mno=97901

Onuma, H., Shin, K. J., \& Managi, S. (2017). Reduction of future disaster damages by learning from disaster experiences. Natural Hazards, 87(3), 1435-1452. https:// doi.org/10.1007/s11069-017-2825-3

Paristiowati, M., Hadinugrahaningsih, T., Purwanto, A., \& Karyadi, P. A. (2019). Analysis of students' scientific literacy in contextual-flipped classroom learning on acid-base topic. Journal of Physics: Conference Series, 1156(1), 012026. https:// doi.org/10.1088/1742-6596/1156/1/012026

Pickett, N. R., Henkin, S., \& O'Lear, S. (2019). Science, Technology, and Society Approaches to Fieldwork in Geography. Professional Geographer, 1-11. https:// doi.org/10.1080/00330124.2019.1639204

Quieng, M. C., Lim, P. P., \& Lucas, M. R. D. (2015). 21st Century-based Soft Skills: Spotlight on Non-cognitive Skills in a Cognitive-laden Dentistry Program. European Journal of Contemporary Education, 11(1), 72-81. 'https:// doi.org/10.13187/ejced.2015.11.72

Rahmayanti, H., Ichsan, I. Z., Azwar, S. A., Kurniawan, E., Irawan, B., \& Titin, T. (2020). Indonesian Student Environmental Attitude of flood during COVID-19: DIFMOL Education Model in 21st Technology. International Journal of Advanced Science and Technology, 29(5), 6245-6253. http://sersc.org/journals/index.php/IJAST/article/view/15628

Reyna, J., Hanham, J., \& Meier, P. (2018). The Internet explosion, digital media principles and implications to communicate effectively in the digital space. ELearning Digital Media, 15(1), 36-52. https:// doi.org/10.1177/2042753018754361

Seema, S., Gupta, M., \& Sharma, R. K. (2019). 21st century skills and sustainability. International Journal of Advanced Science and Technology, 28(16), 507-513. Google Scholar

Siriwardena, M., Malalgoda, C., Thayaparan, M., Amaratunga, D., \& Keraminiyage, K. (2013). Disaster resilient built environment: role of lifelong learning and the implications for higher education. International Journal of Strategic Property Management, 17(2), 174-187. https:/ / doi.org/10.3846/1648715X.2013.806373

Storr, V. H., Haeffele-Balch, S., \& Grube, L. E. (2017). Social capital and social learning after Hurricane Sandy. Review of Austrian Economics, 30(4), 447-467. https:// doi.org/10.1007/s11138-016-0362-z

Toquero, C. M. (2020). Challenges and Opportunities for Higher Education amid the COVID-19 Pandemic. Pedagogical Research, 5(4). https:// doi.org/10.29333/pr/7947

Tsai, M. H., Wen, M. C., Chang, Y. L., \& Kang, S. C. (2015). Game-based education for disaster prevention. AI and Society, 30(4), 463-475. https:// doi.org/10.1007/s00146-014-0562-7 
Urbani, J. M., Truesdell, E., Urbani, J. M., Roshandel, S., Michaels, R., \& Truesdell, E. (2017). Developing and Modeling 21st-Century Skills with Preservice Teachers. Teacher Education Quarterly, 44(4), 27-51. Google Scholar

Velasquez, D. L., \& Evans, N. (2018). Public library websites as electronic branches: A multi-country quantitative evaluation. Information Research, 23(1). Google Scholar

Yusop, F. D., \& Sumari, M. (2013). The Use of Social Media Technologies among Malaysian Youth. Procedia - Social and Behavioral Sciences, 103, 1204-1209. https:// doi.org/10.1016/j.sbspro.2013.10.448 